\title{
Qualification Of Vacant Urban Lands As Potential Green Spaces Used For Optimising The Storm Drainage System Of Resistencia City (Argentina)
}

\author{
Julieta M Daciuk ${ }^{1}$, Valeria Schneider ${ }^{1}$ \\ ${ }^{1}$ Facultad de Arquitectura y Urbanismo, Universidad Nacional del Nordeste \\ valeria_schneider@hotmail.com
}

\begin{abstract}
The increasing rainfall issues related with current humid periods, as part of city of Resistencia's climate in Argentina, impact and affect their population. This city has an inefficient storm drainage system, as a result of human intervention in the natural environment. Moreover, there is a wide range of vacant land that can offer and integrated green open spaces system that could relief and absorb the overflow of rainfall, while ensuring optimum solutions to face floods with less intervention, less environmental impact and low investment. The outcomes of this research have pointed out four key sectors suffering frequent flood and could be relief with green open spaces. This vacant land, are still available to be incorporated as absorbent areas that could also be design a flooding park, offering not only absorbent areas but also could be useful for leisure purposes, available for the community.
\end{abstract}

(C) 2021 IJBESR. All rights reserved.

Keywords: Green open spaces, vacant land, flooded areas, rainfall absorption

\section{Introduction}

The following document it is part of Scholarship research project "Qualification of urban vacant land as potential green spaces for the optimization of the storm drainage system of the city of Resistencia (Argentina). Management proposals and instruments supervised by the MATRP. B. Arch. Valeria Schneider and co-supervised by Mgter. B. Arch. Malena Pérez within the framework of Transfer Agreement with the Provincial Water Administration, according to Resolution \#545/19 of the FAU CD (UNNE). These activities were carried out at the Brian A. Thomson Institute of Urban and Regional Planning of the University of Architecture and Urbanism of the UNNE, seeking to collaborate with the community from the university level, offering urban proposals, to conveniently face the challenges of urbanization in contexts of climate change.
The Greater Resistencia city is situated on the western bank of the Parana river, opposite the city of Corrientes, in the northeast of Argentina. This urban conglomerate includes Resistencia and satellite cities, such as Barranqueras, Puerto Vilelas and Fontana, forming the Greater Resistencia Metropolitan Area (GRMA).

The city is located in a flooding plain, surrounded by embankment, forming polder systems, which limit the possibilities for growth [1]. However, there are several vacant land offering an important option to proper deal with rainfall excesses, and can be part of the hydraulic system in order to contribute and to achieve sustainable development goals assumed at the national level.

At global scale, there is clear evidence of the impacts produced by urban floods. Abhas and Bloch [2] argue that "Floods in cities caused serious challenge not only development but also lives of their inhabitants, particularly residents 
of expanding towns and cities in developing countries", considering trends in urbanisation and climate change which are generating increasingly frequent urban floods and their impacts are accelerating. Several examples of floods reported worldwide have grown significantly in the last 20 years. The number of people affected by floods and economic losses have also been growing.

Although there is controversy at the regional level regarding the reasons for flooding due to rainfall excess, the city of Resistencia is not the exception to the described phenomenon. The issue has increased in recent years, impacting on their population. If the rainfall in this city is analyzed chronologically, it is possible to find different periods, as humid, normal and dry. In humid periods, rainfall reaches extreme values and leads to critical hydric phenomena. At the beginning of 2019, through Decree \# 99/19, the population at the provincial level was declared in a Hydraulic Emergency (1).

In accordance with the commitment assumed by our country at the last United Nations Conference on Housing and Sustainable Urban Development (Habitat III) held in Quito (Ecuador) in October 2016, where a "New Urban Agenda (NAU) was agreed", A fundamental document that promotes sustainable and resilient cities based on policies that include criteria of accessibility, equity, inclusion, participation, security and resilience [3][4]. The challenge of the research has consisted of finding alternative mechanisms that imply the development of alternatives for the management of exposed urban lands that are impacted by rainfall overflows with existing resources, without incurring large investments in physical works, in order to achieve sustainable development goals.

This baseline bonds with the purposes that framed this research, trying to provide information that implies a contribution to nonstructural measures (regulations) as well as new water policies, thus contributing with basic information within the framework of the Agreement and Transfer of Results with the Provincial Water Administration, according to Resolution No. 545/19 of the FAU CD (UNNE).

Based on the above lines, the identified areas can fulfill the role of green spaces that collaborate with humid periods through the absorption of rainfall overflows. The integration of public spaces, flower beds, wastelands and urban vacant lands offer optimum opportunities to be incorporated into a sustainable urban water drainage system.

\section{Material and Methods}

\section{Objectives and Hypothesis}

Course objective: Recognize the flood areas caused by rainfall and then qualify the vacant green spaces as potential resources for the water management of the city of Resistencia.

Particular objectives:

- Develop a methodology according to the topic addressed, which is verified and complemented with bibliographic consultations.

- Identify problems and potentialities of some areas of the city of Resistencia in relation to the issues addressed.

- Prepare a document that represents a contribution to the community through a Transfer Agreement outcomes with the Provincial Water Administration, according to Resolution \# 545/19 of the FAU CD (UNNE).

\section{The Key Issues}

The city of Resistencia is located in what is geographically called: El Chaco Oriental or Húmedo [5]. The climate is humid, with excess rainfall, water infiltration is practically nil, because the surface terrain is made up of clays 
that are impermeable to a depth of 12 to 20 meters. Iriondo and Pauli [6][7] agree that waterlogging due to local rains refers to lands that are temporarily covered by significant and / or intense rainwater, due to a low infiltration capacity, presence of low or depressed areas and deficiency of the drainage network. In turn, urban floods: fundamentally impact the population, their homes and all the available service infrastructure (energy, communications, transportation, etc.).

The problem then arises in relation to two basic situations: The pluvial problems, caused by climatic phenomena with heavy rainfall (approximately $1300 \mathrm{~mm}$ per year), and the location in the alluvial plain where the Negro and Paraná rivers converge.

For its part, the Provincial Water Administration adds that there are anthropic factors that negatively affect the city's rainwater management:

"The embankment system that weighted the urban area, converting the lagoons receiving rainfall excess, acting as urban drainage, from where it is pumped out to Negro River which finally ends in Parana River."

Waterproofing, a result of urban growth, which does not allow water infiltration, causing flooding throughout the urban area. Meanwhile informal settlements and low income populations are settling in forbidden areas by regulations because they are flooding every time the rivers increased their flow, many of them close to enbankment, others close to lagoons."

The city of Resistencia suffer repeated flooding situations, both due to river increased and rainfall, both managed by structural measures, such embankments and non-structural measures like regulations for areas according to their level of hazard like Resolutions \# 121/14 and Resolution \#. 303/17 from Water Administration.
The following Figures illustrates the aforementioned situation, pointing out the rainfall increase in the $2015 / 2019$ periods, data corroborated from local newspapers and images that complement this information.

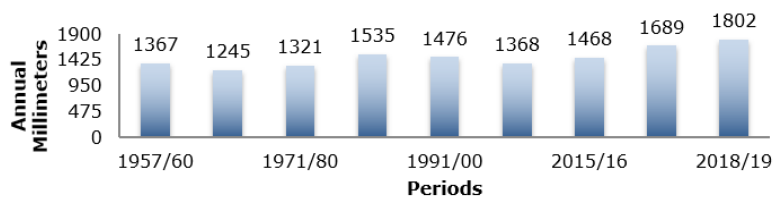

Source: (Authors' analysis based on data obtained from the Provincial Water Administration.)

Figure 1: Annual Average Precipitation Chart

Based on data obtained from the Provincial Water Administration and the Chaco Police, they indicated that the 2018/2019 was humid period, with a total of $1802 \mathrm{~mm}$, exceeding the average by $502 \mathrm{~mm}$, and reflecting the excess rainfall that has elapsed. in January 2019, with a total of $554 \mathrm{~mm}^{2}$.

Based on data obtained from the Provincial Water Administration and the Chaco Police, they indicated that the 2018/2019 was humid period, with a total of $1802 \mathrm{~mm}$, exceeding the average by $502 \mathrm{~mm}$, and reflecting the excess rainfall that has elapsed. in January 2019.

The periods of 2012/2019 was established as a humid periods shown evidence to limit the search at local newspapers information in order to determine the study areas, focusing the analysis on 2019 due to the fact that successive water events have been recorded whose impacts on the city have been relevant.

\section{Green areas}

"The unplanned urban sprawl of Resistencia city and satellite cities have been generating isolated sectors, without linkage with consolidated city core, with the dispersion of activities and uses, functional disconnection, and occupation of flooding areas." [8] 
That is why these natural vacant land together with the green open spaces of the city could be useful to promoted as a network, integrated into the urban planning of the city that complement the current rainfall infrastructure, reducing the accumulation of water in the surface from different sustainable techniques.

The main purpose is to contribute to current rainfall issue, qualifying green spaces based on the surface, state, destination and relationship with other key factors, applying new sustainable instruments such as alternative storm drains.

Additionally, it is necessary to promote greater "permeability" of the urban structure, allowing the citizen to "introduce" recreational open spaces, generating social and sports activities, relating urban activities and linking them to each other. [9]

Furthermore, it is possible to improve the runoff of excess rainfall in natural way linking with suburban areas, through sustainable techniques and achieving broad benefits such how:

- Economic: the reduction of investment, with less maintenance and management of existing conventional pipeline systems.

- Environmental: By reducing the dragging of rainfall over polluted surfaces and improving green spaces as natural reservoir where rainfall excess can end.

- Social: From the valuation and education of society, to enhance the urban landscape with benefits for community, contributing, at the same time, to biodiversity in the urban ecosystem. [10]

\section{Methodology}

In order to examine and to determine the flooded key areas, four instances were defined. The step \#1, or Cognitive Stage, consisted in literature review and data search in different Government Offices such as Resistencia city Council, the Provincial Water Administration, the Chaco Police Department and the National Meteorological Service were consulted. Likewise, it was necessary to collect information from local newspaper, overlapped and cross them with the data provided by the different sources surveyed, for better knowledge of the city, locating the affected areas and defining key sectors to be analyzed in detail, ending with the definition of study parameters and guidelines, towards the next stage of the research.

The step \# 2, consisted in systematization of the information, the analysis and identification of feasible areas of intervention was carried out, processing data obtained from local newspapers and organizing them into a table according to the data collected, pointing out on a map with the identified areas. Registered in each source consulted, with their corresponding images. 
Table 1: Information systematization chart model. Neighborhoods in Development.

\begin{tabular}{|c|c|c|c|c|c|}
\hline DATE & $\begin{array}{l}\text { NEIGHBORHO } \\
\text { ODS AFFECTED }\end{array}$ & Mm/day & SOURCE & LOCATION & IMAGES \\
\hline 08/01/13 & $\begin{array}{l}\square \text { Villa Barberán, } \\
\square \text { Carpincho } \\
\text { Macho. } \\
\square \text { Refugio de los } \\
\text { Humildes }\end{array}$ & $150 \mathrm{~mm}$ & Tres Líneas & & \\
\hline $10 / 01 / 19$ & $\begin{array}{l}\square \text { Barberán } \\
\square \text { Aramburu } \\
\square \text { Carpincho } \\
\text { Macho } \\
\square \text { Emerenciano } \\
\square \text { Don Andrés } \\
\square \text { Ex Campo de } \\
\text { Tiro }\end{array}$ & $250 \mathrm{~mm}$ & $\begin{array}{l}\text { Vía } \\
\text { Resistencia }\end{array}$ & $\begin{array}{ll}0 \\
- & 0 \\
0 & 0\end{array}$ & \\
\hline
\end{tabular}

Source: (Own elaboration based on data extracted from journalistic media)

Table 2: Information systematization chart model. Consolidated Neighborhoods.

\begin{tabular}{|c|c|c|c|c|c|}
\hline DATE & SPOTS OF CONFLICT & Mm/day & SOURCE & LOCATION & IMAGES \\
\hline $14 / 04 / 12$ & $\begin{array}{l}\square \text { Belgrano y Julio A. } \\
\text { Roca. } \\
\square \text { Av. 25 de Mayo y } \\
\text { Vedia } \\
\square \text { Marcelo T de Alvear } \\
\text { y Liniers } \\
\square \text { Av. Italia y H. } \\
\text { Yrigoyen. }\end{array}$ & $40 \mathrm{~mm}$ & $\begin{array}{l}\text { La Voz del } \\
\text { Chaco }\end{array}$ & & \\
\hline 08/03/19 & $\begin{array}{l}\square \text { Av. Marconi y Av. } \\
\text { Hernandarias } \\
\square \text { Av. Italia y } 9 \text { de } \\
\text { Julio. } \\
\square \text { Av. San Martín y } \\
\text { Juan B. Justo. } \\
\square \text { Av. Las Heras y } \\
\text { Arturo Illía }\end{array}$ & $78 \mathrm{~mm}$ & $\begin{array}{l}\text { Diario } \\
\text { Chaco }\end{array}$ & & \\
\hline
\end{tabular}

Source: (Own elaboration based on data extracted from journalistic media) 


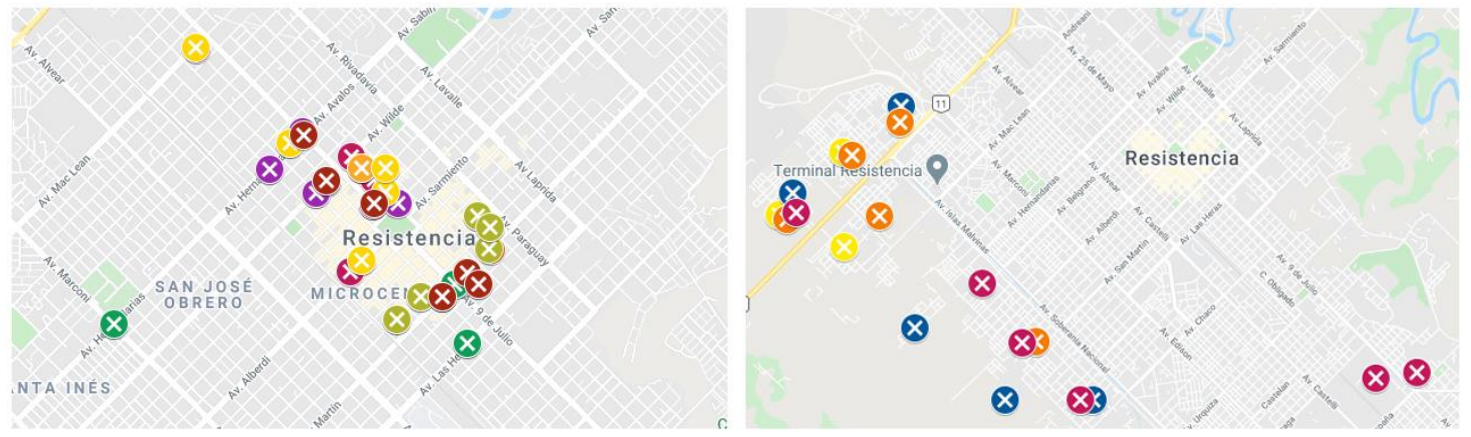

Source: (Own elaboration based on data extracted from journalistic media)

Figure 2: Synthesis maps of flooded areas.

\section{Result and Discussion}

\section{Determination of Key Flooded Areas}

After ordering the information into two diagrams according to their features, four (4) study areas were defined according to the frequency of events, two (2) corresponding to urbanised area, in correspondence with levels of high waterproofing, built-up areas, density, and inefficiency in storm drains in their receptive capacities.

On the other hand, another two were delimited to suburban areas, with greater availability of green open spaces, scarce storm drain pipeline infrastructure, and less waterproofing and builtup areas and density. For its selection, surface area and representative role were taken into account, which is a relevant indicator that allows the application of water improvement techniques. The chosen areas were:

- Area \# 1: it is delimited by Rivadavia, Sarmiento, Alberdi, and Moreno Avenues, together with San Roque street. It is a consolidated area of 140 hectares. With commercial, administrative, residential activities, among others. It concentrates most of the activities of the city, since it is located in the historic center of Resistencia.

- Area \# 2: is delimited by Sarmiento, Alberdi and Paraguay Avenues, together with Juan Dios
Mena and Rodríguez Peña Streets. It is a consolidated area of 140 ha. With commercial, administrative, institutional, residential activities, among others. It concentrates most of the activities of the city, since it is located in the historic center of Resistencia.

- Area \# 3: it is delimited by National Route \# 11, Charata, Nahuel Huapí Lake and Ushuaia Streets. It is a consolidated area of 119 hectares. With mainly residential activities. It is a developing sector, populated for less time than the consolidated areas, so it still has many potential urban voids for sustainable drainage complementary to the traditional ones.

- Area \# 4: it is delimited by Soberanía Nacional, Las Heras and Chaco Avenues, together with Ushuaia street. It is a consolidated area of 89 hectares. With mainly residential activities. As in the previous case, it is a developing sector with greater urban voids than the consolidated areas, potential for sustainable storm drains, although this sector has less availability than area \# 3 .

\section{The Digital Support Sources}

The Geographical Information Systems (GIS) was the key digital supporting tools for land information management and decision-making support, allowing to overlap and cross data from public institutions and newspapers using Qgis and Google Mymaps, tools that made it 
possible to generate a useful database for government offices that require it.

With the identification of flood areas, vacant green spaces were defined and quantified. Specific uses and a priority order were established, while some potential lands able to be included in a shor, medium or long term were also considered. In this way, conditions to gradually structure a network of absorbing green spaces can constitute an integral solution to the identified problem.
In accordance with purpose stated at the beginning of this research, Green Spaces must be articulated as a "system", conceived as a network belonging to the urban area, where the various typologies interrelated with each other, with the natural landscape and with components of the urban landscape, they allow "introducing nature into the city and moving it through its different channels or corridors" promoting the biotic diversity of the urban ecosystem [11].

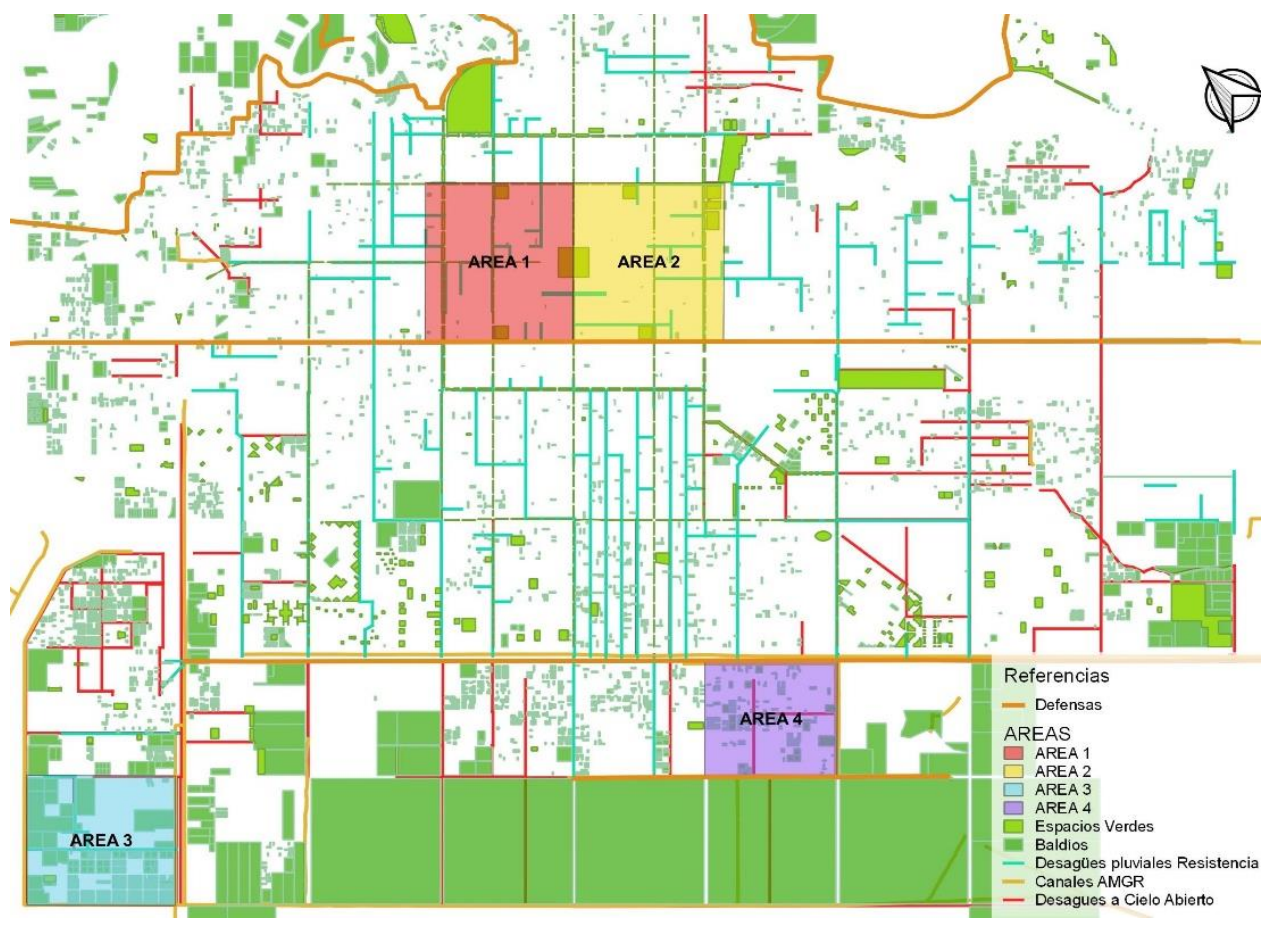

Source: (Own elaboration based on data extracted from Public Organizations)

Figure 3: Synthesis Map.

Starting with the study areas with different features, the four chosen sectors were compared and overlapped with the regulations applied to the city, according to areas with different levels of hazards based on the Regulations of the Provincial Water Administration, in order to provide updated information, through a Transfer Agreement with the Institution. (Resolution \# 545/19).

Additionally, it was possible to verify that urban growth should be regulated in places with different levels of rainfall hydraulic risk, but also the built up areas of the city core of Resistencia should be limited, though they have drainage pipeline, it is inefficient; that is because it continues with their real estate development, without proper infrastructures, being affected by rainfall in the same proportions as peripheral areas that have less waterproofing, compromising the proper functioning of the city. 


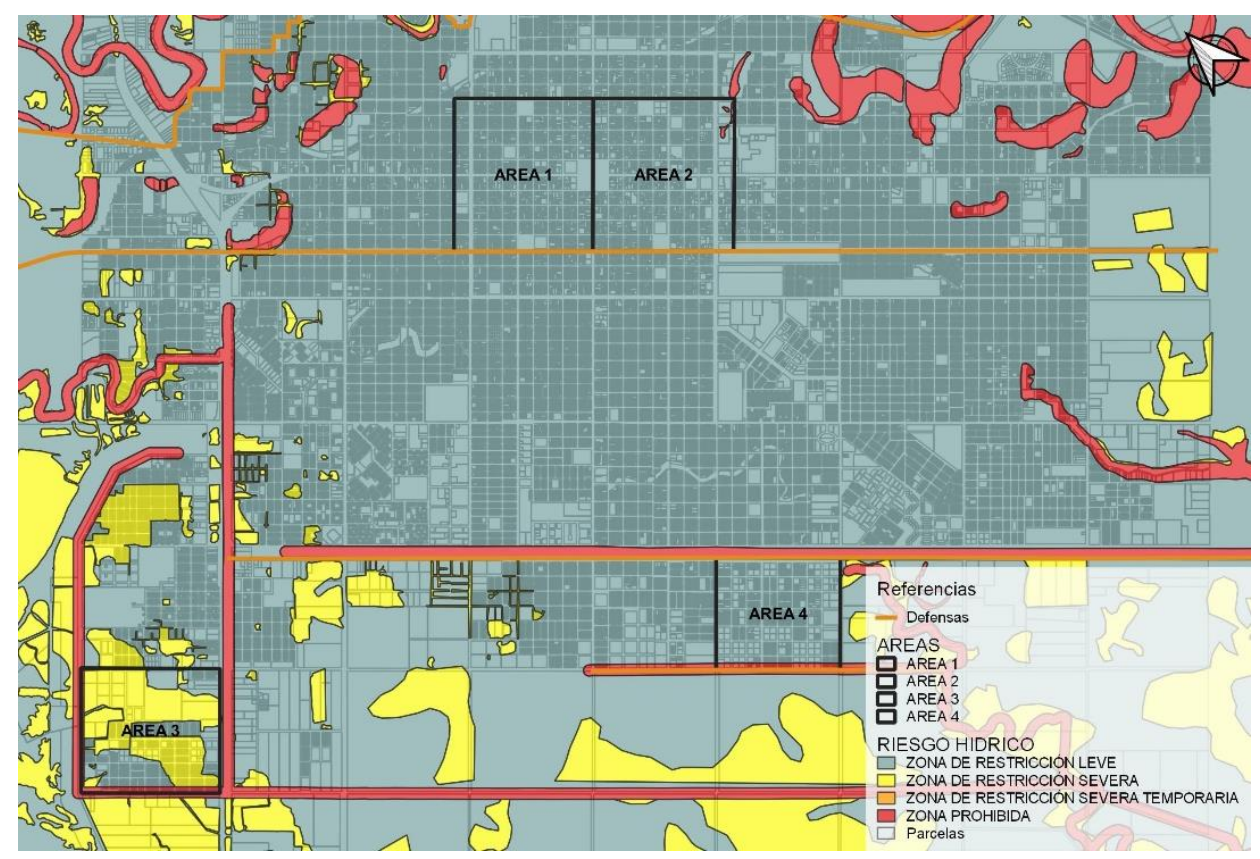

Source: (Self elaboration based on data provided from Public Organizations)

Figure 4: Water Risk Resolution \#121 | 14

Based on Resolution \# 121/14 and 303/17 of the Provincial Water Administration (APA) and understanding that their foundation is to guide urban growth in the highest topographically high places to prevent damage that could be caused by different types of floods, being that the year prior to the approval of Resolution 121/14 "the APA had a water risk zoning for flooding for the entire Metropolitan area, but associated only with flooding of the Negro rivers, the Canal de la National Sovereignty, of the Arazá. " Said regulation arose in the context of the events suffered in 2009, where heavy rains were recorded over the metropolitan area, where many residential neighborhoods that had a feasibility to urbanize from the APA were flooded by high rainfall and by the inconveniences presented by the natural and artificial drainage systems; encouraging the authorities to zoning the metropolitan area, to guarantee habitability to any residential neighborhood, either by protecting them from the floods of the Negro River, the Arazá and the Soberanía Canal, as well as from rains; It is a non-structural measure that tends to plan the growth of the Great Resistencia, taking into account the storm drain service of any place where you want to build houses [12].

Under this argument, the study areas were analysed in order to determine whether the sectors that are currently contemplated in said zoning regulations for rainwater risk are the only ones affected in the city, finding significant data that constitute the main contribution of this work that they can provide recommendations not only for APA but also for other organisms that influence urban development decisions in the study area.

As a result of the analysis of the study sectors superimposed with the Water Risk regulations, areas 1-2 are demarcated as water risk with slight restriction, confirming that there were several episodes where floods occurred due to rainfall in these sectors.

Last, but not least, in areas 3 and 4 you can see areas of severe and prohibited restriction, which indicates as a priority not to increase the 
percentage of waterproofing and to apply storm drainage works that accelerate the runoff of water into the canals. corresponding.

In stage number 3 of this work, called Diagnosis and recommendations, each study area was specified through a quantitative assessment of the data obtained. Characteristics of each sector were identified and the most suitable, viable and necessary green spaces were ordered through a file according to development criteria, budget and deadlines for the application of techniques. Then it was calculated through information on green space surfaces, the waterproofing surface of each area, and the identification of the existing storm drains in each sector, in order to make the necessary conclusions and recommendations according to the characteristics of each sector.

Faced with this scenario, the need to incorporate absorbent green spaces in both encountered situations gains value; being possible and a priority the provision of free spaces that "coalesce" for a dispersed city, essential if a compact city is aimed, being much more efficient the distribution of green areas in small residential-scale public spaces than in large peripheral-scale parks urban-regional, causing a greater "permeability" of the urban fabric, allowing "to introduce" nature into the city [11].

According to the classification described and understanding its importance to provide quality of life to the population, it oriented the work towards the incorporation of a classification of available green spaces, based on their function as absorption spaces and rainwater retarders, which would also improve the quality of life of the inhabitants.
The qualification is based on 3 types of green spaces: More suitable, viable and necessary, defining the criteria based on the $\mathrm{m} 2$ of existing and empty urban green spaces, and understanding that without them the current rainfall problem would worsen.

$>8000$ m2: Necessary: Green spaces that are currently acting as large absorption spaces are considered necessary. Without them, even more excess rainfall would accumulate in the streets, further aggravating the runoff time into existing drains, causing flooding and collapse of the current system. These are existing spaces that are currently in use, mostly recreational, so they have isolated activities and a surface that could be used to develop sustainable drainage techniques in the short and medium term.

$>2000 \mathrm{~m} 2$ : More suitable: Spaces that can be used strategically to take advantage of the absorbent surface are considered, such as flowerbeds, they usually contain recreational activities or simply fulfill their function of separating secondary routes of circulation according to the directional direction. They can be incorporated into short-term planning, due to their urban availability, since their modification would not cause the change in their current use and their average area of application would not involve large economic expenses.

$\leq 2000 \mathrm{~m} 2$ : Feasible: These are spaces with a smaller surface, such as vacant lots, flower beds with a smaller surface area or urban interstices, which are useful while they are empty as part of the network of green spaces. They can be temporarily incorporated into the network, since their use could be modified by their owners. They are a good complement to the necessary and more suitable spaces. 
Table 3: Model of the chart for quantification and qualification of green spaces. Case 1.

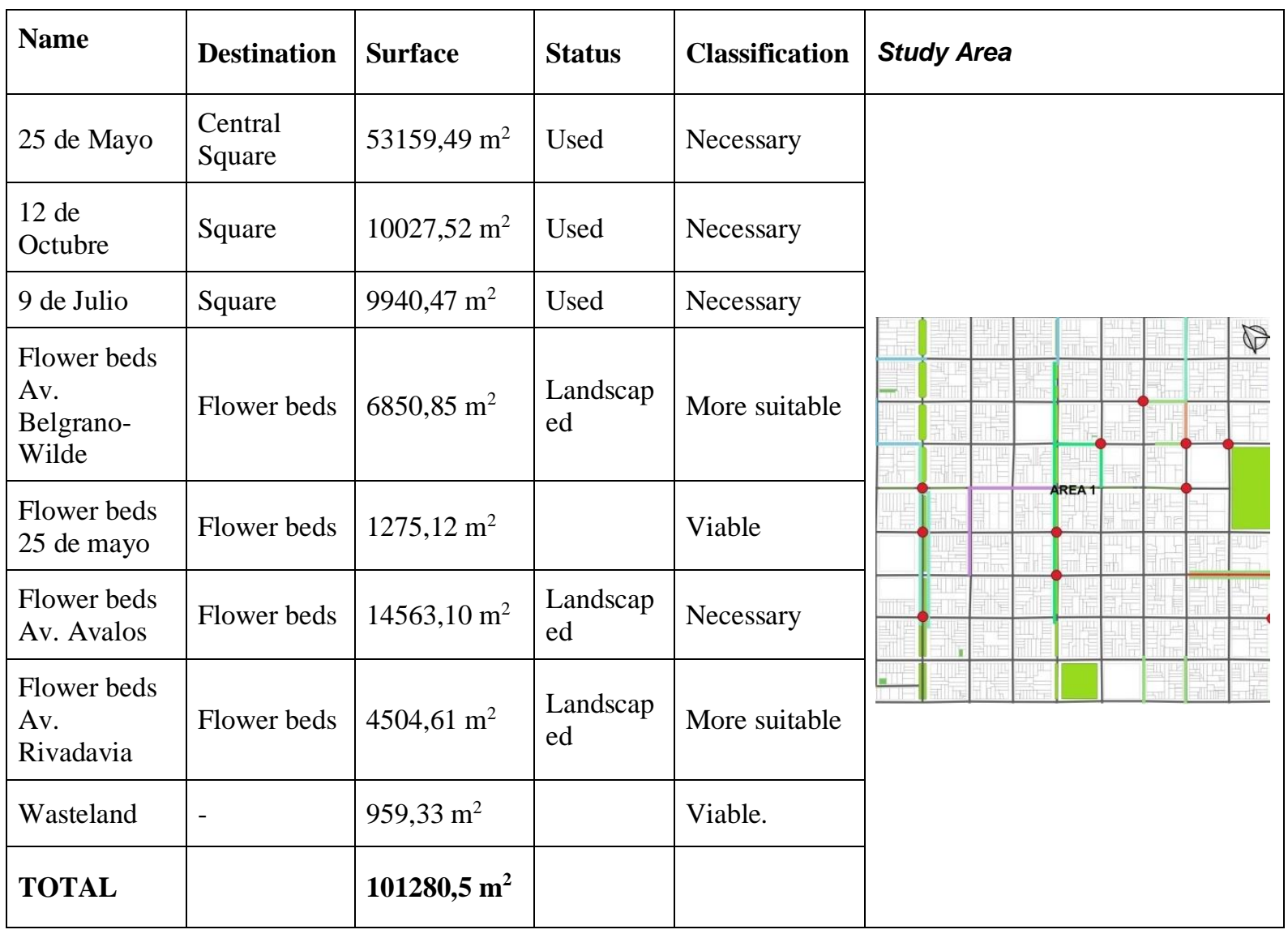

Source: (Own elaboration based on Green Spaces of the Municipality of Resistencia)

Waterproofed Surface: from the data obtained by Geo-reference means, such as the total $\mathrm{m} 2$ of green spaces in the study areas, the following calculation was made to determine the nonabsorbent surface, bearing in mind that it is taken from the parameter of waterproofed surface to the plots and paved streets and as absorbent areas to the sectors of possible intervention.

Total Area - Green Area $=$ Waterproofed
Surface

$1390983,919 \mathrm{~m}^{2}-101280,488 \mathrm{~m}^{2}=$ $1289703,43 \mathrm{~m}^{2}$

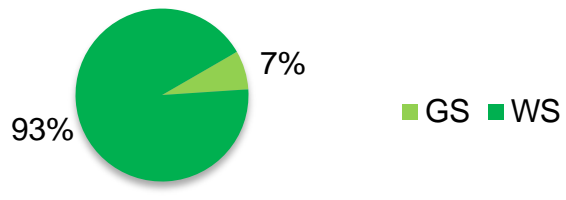

Source: (Self elaboration based on data obtained from systematized data from newspapers)

Figure 5: $x x x x$

We can see how the ratio of green spaces available in the sector with the waterproofed surface is only $7 \%$ over $93 \%$, which makes it completely necessary for the storm drainage runoff process to be carried out with pipelines systems. At the same time, the current pipelines drainage system could be compensated, with sustainable techniques on this $7 \%$ of absorbent 
spaces, reducing the flow of rainfall over these waterproof areas to avoid the collapse of the system.

The same process was carried out with all the areas determined for study, obtaining a green absorbent spaces (GS) ratio: $9 \%$ over $91 \%$ of waterproof spaces (WS) in case 2, but nevertheless, in growing areas the reality is different, as areas with less waterproofing, obtaining a relationship: (GS) $48 \%$ over $52 \%$ of waterproof (WS) in case 3 and (GS): 19\% over $81 \%$ of (WS) in case 4 , the study is intended to generate guidelines for management and planning of urban areas for flood mitigation, considering a large supply of urban vacant land that could be occupied without proper control over absorbent spaces, concluding with the same inconveniences as consolidated areas.

\section{Conclusion}

The following research concludes: the built up and downtown areas have shown serious storm drainage issues mainly linked with insufficient section of pipelines related with density increased. The urbanization and its impacts on the waterproofing of lands are linked to a series of measures implemented in the last 20 years mainly, such as Regulation \# 5403/01 promoting densification increased without the proper infrastructure. Therefore, faced with this issues, various possible scenarios are presented, on the one hand, structural measures such as expansion of drainage pipelines, which would demand a high investment; on the other hands, non-structural measures, updating of regulations, including new package of measures to address downtown areas and feasible options to limit the impacts of increasing waterproofing, considering the possibility of incorporating absorbent green spaces, such as vacant urban lands, and spaces with different uses such as squares, through a sustainable urban drainage system that allows the strengthening of current drainage pipelines system.
Additionally, this research outcomes, have identified four (4) key sectors as most affected in rainfall seasons, and some green vacant land were also pointed out to relief this sectors. In the southern areas of Resistencia city, more surface of vacant land is still available to be incorporated as absorbent areas. This was the main objective to organize an International Workshop to design a flooding park to offer absorbent areas that could also be useful for leisure purposes, available for the community.

In this sense, the research analyses feasible options to provide relevant evidence for future investigations such as Sustainable Urban Drainage Systems, in turn, recommendations were developed such as promoting forums for debate on them, and the writing of a Guide explaining the importance the SUDS in such a way that it serves to raise awareness in society towards natural environments, and also guides technicians and political leaders on the management of the different alternatives according to the characteristics of the sectors to be applied.

\section{Recommendations:}

Based on the analysis carried out, it is recommended:

- Examine the scope of Resolution \#121/14 throughout the metropolitan area, in particular, incorporating measures aimed at mitigating the effects of rainfall excesses in areas with full infrastructures within city of Resistencia, including regulation of new buildings.

- Preparation of a storm drainage management regulation encouraging the use of sustainable urban drainage and helps to update and promote change in satellite cities of Greater Resistencia Metropolitan Areas and their city councils.

- Create a Network of Green Spaces, including: vacant lands, squares, and any green open space that could be useful as an absorbent surface. One starting point could 
be the organization of a Workshop with the purpose to design a chosen vacant land, as a Flooding Park.

- Promote a coordinated network between different city council of Greater Resistencia together with government institution like the Provincial Water Administration, to facilitate change and decision-making regarding rainwater management, strategies and programs for flood risks.

\section{References}

[1] Peréz Malena, Schneider Valeria. Greater Resistencia Study Case: Greenfield and Increased Densification. NALARS Jurnal Arsitektur FT UMJ. 2012;11(1):25-35. ISSN: 1412-3266

[2] Abhas, K.; Bloch, R. Et. al. Ciudades e Inundaciones". Guía para la Gestión Integrada del Riesgo de Inundaciones en Ciudades en el Siglo 21. International Bank for Reconstruction and Development /International Development Association or The World Bank. 2012;P.59.

[3] HÁBITAT III. "New Urban Agenda". 2017. United Nations Conference On Housing And Sustainable Urban Development (Hábitat III) held in Quito, Ecuador, October 20th 2016. United Nations publication issued by the Habitat III Secretariat. ISBN: 978-92-1-132736-6.

[4] Plan Estratégico Territorial. Argentina Urbana. Secretaria De Planificación Territorial Y Coordinación De Obra Públicas. Ministerio Del Interior, Obras Públicas Y Vivienda, Presidencia De La Nación. Ciudad Autónoma De Buenos Aires, 2018.

[5] Alberto, Juan A. El Chaco Oriental Y Sus Fisonomías Vegetales. 2006. Resistencia: Revista Geográfica Digital. Vol. \# 5.Instituto de Geografía de la Facultad de Humanidades. E-ISSN 1668-5180

[6] Iriondo, Martín. Environmental Changes On Chaco Argentina - Bolivia Region In Last Thousand Years. 2006. Resistencia: Folia Histórica del Nordeste \#16. Journal of Institute of Research on GeoHistoric (IIGHI).ISSN 0325-8238; E-ISSN 2525-1627.

[7] PAOLI, Carlos U. Integrated Flood Management. 2015. Santa Fe: European Union. Report available on https://aquaknow.jrc.ec.europa.eu/sites/default/files/info rme_curso_gic-2016.pdf.

[8] PÉREZ, Malena; TOFALETTI Nadia. "Hypothesis Of Urban Articulation 1, The City And The River. Towards A Sustainable Urban Integration ". 2015. $6^{\circ}$ Seminar on Urban Policies and Sustainable. Facultad de Arquitectura y Urbanismo (IPUR) - Instituto de Planeamiento Urbano y Regional - BAT - Brian
Alejandro Thomson. Resistencia, 4 y 5 de junio de 2015. ISSN 1851-3506

[9] PERÉZ, Malena; SCHNEIDER, Valeria. “Greater Resistencia Study Case: Greenfield And Increased Densification". 2012. Jakarta: NALARS Jurnal Arsitektur FT UMJ, Vol.11,No.1, Edition January 2012. pp. 25-35. ISSN: 1412-3266

[10] PERALES MOMPARLER, Sara. "Soluciones Basadas En La Naturaleza Para La Gestión Del Ciclo Urbano Del Agua”. 2018. Recuperado de: https://www.camarazaragoza.com/wpcontent/uploads/2018/11/Presentacion-Sara-Perales.pdf [11] PÉREZ, Malena; SCORNIK, Carlos. "Urban Observatory. Of Resistancia - Corrientes Cities. Biodiversity And Urban Landscape Indicators. Outcomes". 2013. Proceedings of 6th Conference on $\underline{\text { Research + Teaching + Extension + Management- }}$ Facultad de Arquitectura y Urbanismo de la UNNE. Resistencia.

[12] ROHRMANN, Hugo. "The Provincial Water Administration Published Urban Water Risk Zone Due To Rains". Newspaper Press "La Voz del Chaco". 2013. Newspaper Tag. Digital version available on: http://www.diariolavozdelchaco.com/notix/movil/index. php?s=nota\&id_nota $=24865$ 